\title{
1. Strategic partnerships, international politics and IR theory
}

\section{Andriy Tyushka and Lucyna Czechowska}

\subsection{THE RISE OF STRATEGIC PARTNERSHIPS IN WORLD POLITICS}

Strategic partnerships (SPs) constitute a novel form and feature of the evolving international relations system and represent a new principle for organizing international life. Seen broadly, strategic partnerships represent a type of special relationship and thus are not unique or new at all. However, should one take a closer look into the internal mechanics of the partnership phenomenon and explore its distinctive foreign-political functions from its changing geostrategic context, it becomes clear that with the reconfiguration of the international relations system since the early 1990s, strategic partnerships have become the necessary key to cope with systemic and issue-specific international challenges.

It is difficult to trace the path back to the first strategic partnership formed post-1990. The problem is of both an empirical and analytical nature as there is still no consensus in the literature as to what elements constitute the idea of a strategic partnership and whether labelling a relationship as such is sufficient to regard bilateralism as a strategic partnership. Most authors who searched for the roots of the phenomenon contend that the agreement between US President Bill Clinton and Russian President Boris Yeltsin in 1994, which set forth 'a new stage of mature strategic partnership based on equality, mutual advantage, and recognition of each other's national interests' (Moscow Declaration, 1994), encompasses the first of its kind (cf. e.g. Envall and Hall, 2016, p.89; Michalski and Pan, 2017b, p. 13; Nadkarni, 2010, p.46). However, the long abandoned strategic partnership between the US and Turkey, which was re-invigorated in early 2018, was in fact established in 1992. Brazil and China forged their strategic partnership in 1993. Thus, at least two other partnerships of this kind were in place before the 1994 US-Russian deal was struck.

Since 1993, when China made its first strategic partnership with Brazil, and by 2014 China had forged close to 70 strategic partnerships 
of different types (FMPRC, 2015), thereby creating a web of truly differentiated strategic links with both major and emerging powers as well as with international organizations worldwide. Among international organizations, China's strategic partners are the Association of Southeast Asian Nations (ASEAN), the European Union (EU), the African Union (AU), the Arab League (AL) and the Community of Latin American and Caribbean States (CELAC). India has cultivated 20 strategic partnerships, including with the European Union. Japan has forged about half as many, but 'is quickly adding to the list' (Envall and Hall, 2016, p. 90).

As one of the first international organizations, NATO began launching partnerships with non-member countries in the early 1990s in its efforts to foster peace and development. The Alliance's comprehensive Partnership for Peace PfP policy framework embraces now as many as 21 NATO partners across the globe. The EU has ten official global strategic partnerships (with the US, Canada, Mexico, South Korea, South Africa, Japan, Brazil, India, China and Russia) and a number of policy frameworks or issue-specific strategic partners, such as the Eastern Partnership (Eap) and associated countries.

Furthermore, the EU has forged four institutional partnerships with other regional organizations namely NATO, ASEAN, AU and CELAC. The Andean Community (CAN) also pursues development and regional economic integration partnerships, including the 'associated membership' format. With the extension of interest and presence of the Russia-led Eurasian Economic Community (EAEU) to the Latin American region (Eurasian Economic Commission, 2017), the Andean Community also forged an economic development partnership with EAEU for the purpose of 'fostering the bonds of mutual cooperation with [other] organizations of regional integration', thus confirming 'the opening' of CAN for interregional partnerships (SGCAN, 2017), which is a rising trend today.

ASEAN's partnership policy was first conceived as early as 1974, when it granted Dialogue Partner status to Australia, thus predating the systemic proliferation of strategic partnerships as we know them in a polycentric international context. In its current form, ASEAN's network of strategic partnerships lists eight more countries (the US, China, Canada, India, Japan, South Korea, Russia, New Zealand) and one international organization - the European Union. ASEAN's partnership network evolved not only in terms of expanding its partnership web but also in terms of further diversification of partner-engagement formats: 'In conducting ASEAN's external relations, the ASEAN Foreign Ministers Meeting may confer on an external party the formal status of Dialogue Partner, Sectoral Dialogue Partner, Development Partner, Special Observer, Guest, or other status' (ASEAN, 2018). Clearly, the evolving international 
strategic environment stimulates the development of new flexible forms of international association and engagement among acting partners.

It would be a daunting task to establish the precise number of SPs across the globe today - among other reasons, not all states' and international organizations' foreign policy bureaucracies keep a systematic and tidy record in this regard. Renard (2013, p. 302) goes even further to claim that '[most] governments probably do not even realize how many they have signed'. For some, this is a consequence of bureaucratic negligence or underperformance; for other actors, the issue of keeping a record might be of lesser to no relevance (which also shows their understanding of strategic partnerships). For another group of actors, such as China for instance, the matter is about political sensitivity - and thus an unwillingness to make multiple hierarchies of 'strategic', 'comprehensive', 'constructive', 'privileged', 'development' and other partnerships broadly visible (Bang, 2017; Oviedo, 2006).

On the empirical side, the existence of both formal and informal strategic partnerships and the ways of labelling them (which does not necessarily include markers of being either 'strategic' or a 'partnership') complicates the task even further. For instance, the 'American way of partnership' has prompted the US to forge over 60 formal strategic partnerships with other states and over 40 informal partnerships and so-called strategic dialogues, which furthermore do partially overlap (Hamilton, 2014).

By 2000, Ukraine had allegedly established strategic partnerships with 19 countries (Saprykin, 2001), including one in 1997 with what is now openly hostile Russia. From 1995-2001, Ukraine proclaimed its partner relations with such states as: Argentina, Azerbaijan, Belarus, Bulgaria, Canada, China, Finland, Georgia, Germany, Hungary, Israel, Moldova, Poland, Romania, Russia, Slovakia, Turkey, the US and Uzbekistan as all being 'strategic'. Remarkably, only six out of the declared 19 strategic partnerships - i.e. Ukraine's relations with Azerbaijan, Bulgaria, Poland, Russia, the US and Uzbekistan - have been formed bilaterally as such; the remaining 13 partners have merely been unilaterally proclaimed by Ukraine as strategic. This perfectly illustrates in practice the imperfect situation that exists with strategic partnerships. Strategic partnerships, understood as a bilaterally established form of relationship, do not necessarily coincide in number and substance with the lists of strategic partners understood as strategically important that actors may unilaterally cultivate, contend or plan to have among their strategic partners.

The surge of the idea of strategic partnerships is impressive. Its intensive proliferation in international relations appears phenomenal also because the term is not a domain-innate idea. EBSCO's Academic Search Complete returns a total of 8900 results (as of 20 July 2018) for the search term 
'strategic partnership'. The vast majority of these originate from business and management studies followed by political science and international relations (IR) writings on the topic.

The disciplinary distribution of 679 topic search results for 'strategic partnership' from Clarivate Analytics' (until 2016 - Thomson Reuters) Web of Science clearly shows the enhanced use of the term primarily in IR and political science disciplines, including area studies (344 records), followed by searches for business and economics, including management studies (177 hits altogether), and other fields of studies such as industrial engineering (51 hits) and educational research (36 hits).

Notwithstanding its recent introduction to the discipline, such popularity of the term within IR and political science literature illustrates a successful migration of the idea of strategic partnerships from business and organizational studies from which it originates (herein both 'strategic partnerships' and 'strategic alliances' are used to connote the idea).

In the IR/FPA (foreign policy analysis) domain, strategic partnerships have become very 'fashionable' (Renard, 2013, p. 302), 'coming into vogue at both a global and regional level' (Envall and Hall, 2016, p. 90). In international relations, strategic partnerships are an emerging mode of international engagement and a vector of foreign-political association in a polycentric (multipolar, multinodal, post-bi/unipolar) and poly-agential (multi-power, multi-actor, multi-agency) world. Symptomatically (and rather self-defeating as to the idea of denoting a special - and thus rare if not unique - type of relationship), strategic partnerships are also becoming a trend in foreign policy, whereby their absence from an actor's foreignpolitical toolkit matters no less than their practice. Both global powers and small states, as well as international organizations, strive to devise strategic partnerships of sorts to both cater to their foreign-political agendas and to avoid being identified as 'partnership-free' (partnerless or unpartnered) actors. The phenomenon therefore unfolds its significance as a policy- and an image-relevant aspect of modern international relations.

\subsection{THE PROMISE OF STRATEGIC PARTNERSHIPS IN INTERNATIONAL RELATIONS}

However, perhaps less straightforward remain the reasons why strategic partnerships have emerged and proliferated - and why now? According to Nadkarni (2010, p.45), 'structural, regional, and civilizational modifiers' could help explain why, since the end of the Cold War, international actors have departed from the alliance paradigm and instead embraced partnerships. Along with global power shifts and the diffusion of power that 
demand more flexible forms of international cooperation than alliances' frameworks can offer, the civilizational and structural factors are said to be less conducive to alliances at the regional level as well. Furthermore, three other contemporary factors - economic globalization, non-state security threats, and nuclear weapons - account for the decision of emerging global powers and middle powers 'to steer clear of formal alliances' (Nadkarni, 2010, p.45). Paul (2018) posits that greater incentives to cooperate - for both small and large powers alike - arise 'when balance of power meets globalization', a permeating feature of twenty-first century politics. In new times and realities actors seek new forms of cooperation and problemsolving. Laipson (2015) argues that 'for 21st-century problems, states seek partnerships, not alliances'. Menon (2007) also points to the 'end of alliances' not least because of their rigid, limiting and exclusionist nature. In many regards, the twilight of the alliances era is seeing the dawn of the partnerships age - and many (though, not all) of the functions that alliances have performed are now substituted (sometimes also duplicated) by SPs and the international relations system has adapted the practices of strategic partnerships.

Like alliances, strategic partnerships are inherently related to security issues. Renard (2016a, p. 33) notes that it is hardly imaginable that a strategic partnership worth the name could afford not to put security issues at the centre of its agenda; [t]here is, after all, a very large overlap between strategic and security issues'. A Secure Europe in a Better World: European Security Strategy, the EU's first security strategy and the first foreign policy manifesto which explicitly introduced strategic partnerships as a foreign policy principle, emphasizes the relevance of SPs for the EU's security: 'there are few if any problems we can deal with on our own. The threats described above are common threats, shared with all our closest partners. International cooperation is a necessity. We need to pursue our objectives both through multilateral cooperation in international organizations and through partnerships with key actors' (European Council, 2003).

Whereas the security component, be it explicit or implicit, narrow or broadly conceived - can be identified perhaps in every strategic partnership, not all SPs are security-driven and security-based. SPs cover a broad range and may be issue-specific or all-encompassing. For instance, the EU has environmental SPs with Brazil, India, China and South Africa (Grevi and Renard, 2012). With its ten official strategic partners, the EU has also developed cyber partnerships (Renard, 2014, 2018). India, on the other hand, has made efforts to expand its own web of strategic partnerships for economic development (Nath, 2014), including with the European Union (Sachdeva, 2015, pp. 14-19). 
Broader partnerships that either encompass a number of interaction areas or gradually build upon actors' strategic convergence (in goals, roles, worldviews) have proliferated as well. Examples include the EU-Japan 'normative partnership' which is still in the making (Hosoya, 2012) or the recent, all-encompassing EU-Brazil SP, which covers 'more than meets the eye' (Ferreira-Pereira, 2016, p. 55). The practice shows that strategic partnerships go well beyond security and only by way of exception draw on a single area of interaction. Conventional wisdom suggests that broad partnerships should be the more enduring.

Strategic partnerships have both a form (format) and a process, whereas their purpose (function) may and does actually vary from context to context. For small and middle-sized powers, achieving the privileged status of a strategic partner with more powerful international actors serves as a tool for an indirect assertion of their strategic relevance in international affairs, therefore transcending the benefits of a merely bilateral goal-oriented strategic cooperation. For regional and global powers, the size and density of their strategic partnership webs enable actors to be active stakeholders in regional affairs both near and far, thus transcending the image-related benefits of widely recognized strategic relevance. Thus, in principle, strategic partnerships can be formed between 'emerging and established powers' alike (Kliman et al., 2014).

Actors' motivations behind forging strategic partnerships are as various as their motivations to engage in any other form of international strategic interaction, whether it be of a cooperative or competitive character. For instance, Australia's interest in deepening strategic ties with ASEAN lies in gaining an additional 'strategic hedge' against the growing uncertainty in the Indo-Pacific region (WPR, 2018). For China, strategic partnerships have 'a clearer purpose in sight, namely, to shape an international environment that is propitious to its rise as a global power' (Michalski and Pan, 2017 b, p. 14). In particular, the China-Russia strategic partnership may be regarded as both a platform that enables an additional strategic hedge for the rising powers under the Western hegemony, and as 'an axis of (tactical) convenience', driven by 'instrumentalism and opportunism' (Lo, 2008, p. 53; cf. also Brzezinski, 1997, pp. 116-17, 170).

Alongside the international challenges and opportunities, strategic partnerships may equally be enabled or constrained by salient domestic factors of the partners in question (Trinidad, 2017). Without doubt, cultures of strategic and security, as well as political or socio-economic type regimes with a leadership personality may, too, generate the will to cooperate and forge a strategic partnership relationship or contrariwise, fail to deliver such. However, this is not the analysis level which this book project embraces. 
It must be made explicitly clear that strategic partnerships are neither bound to emerge from friendly relations or among friendly powers, nor are they bound to necessarily turn rivalling powers into allies. They provide an incentivized form of engagement and cooperation-while-at-competition. Following Blanco (2015), strategic partnerships are used to 'define relationships as complex, like the one between India and the EU, and straightforward commodity-based ones as exist between Argentina and China' (p. 53). Strategic partnerships have become the new wild card of international relations for they enable interaction and engagement between both friendly and rival, or competing powers as well as between those who are neither allies nor competitors. By virtue of this flexibility, strategic partnerships appear indispensable for strategic interaction in the twenty-first century.

Obviously, strategic partnerships have become 'a central feature of the early twenty-first century diplomatic discourse', which speaks of their rhetorical significance but also bears nasty consequences for the assessment of their policy-related significance. The term's inflated rhetorical use leads to an equivocal situation where strategic partnerships 'mean everything - and thus mean little or nothing' (Renard, 2013, p. 302). The New York Times Chronicle reveals that 82 per cent of the articles the outlet published in 2012 , in one way or another referred to the topic of strategic partnerships (NYT Chronicle, 2015).

This trend can be interpreted in two ways - that is, signifying the rise of this phenomenon and its policy importance, as well as fixating the inflated use of the discursive frame thus devaluing the significance of its policy. Regrettably, and rather confusingly, both interpretations can be held valid, and oftentimes the empty rhetorical shelling overshadows the perception of the real political significance of strategic partnerships practice.

Envall and Hall (2016, p. 88) maintain that in Asia, strategic partnerships are 'a fundamental component of regional security dynamics'. Grevi (2012, 2013) disentangles why EU strategic partnerships matter for the Union's efforts to assert the EU as a global player, advance its economic and development goals, as well as channel its preferences for structuring the global governance processes.

In 2009, then US Secretary of Political Affairs, William J. Burns explained the impetus behind the American strategy of partnerships in his Cyril Foster Lecture at the University of Oxford, where he asserted that the coming age of 'the partnership imperative' is 'a neat bumper-sticker and a handy slogan' but also 'an exceedingly difficult task to carry out in practice'; nonetheless there is evidently a crucial need to 'develop new tools of leadership and cooperation' and use those 'to build a new architecture of cooperation' (Burns, 2009). Given that such 'partnership imperative' informs the foreign policy of the current lonely superpower, one should 
not wonder why middle range or regional powers, as well as smaller powers, make commitments to the promise of partnership.

Indeed, in an increasingly interdependent and complex international system, strategic partnerships represent a flexible and a multi-purpose foreign policy instrument in the toolbox of both the world's leading, rising and smaller powers as well as non-state actors - and first and foremost, international organizations of a greater scope of authority and international engagement calibre.

\subsection{THE STATE OF THE ART IN THE STUDY OF STRATEGIC PARTNERSHIPS: THREE WAVES (SO FAR)}

As both the practice and, to a much greater extent, the use of strategic partnerships as political rhetoric proliferated, so did the literature on the phenomenon. After a two-decades delay, there was a nearly exclusively empirical focus on the most visible international cases. It would be difficult to disagree with Renard (2013) who argued that 'most of the literature on strategic partnerships is a mere recycling of the existing literature, and there is therefore a profound lack of understanding of strategic partnerships as a foreign policy instrument or as a strategy' (p. 302). Of course, exceptions do apply.

Now, the mushrooming amount of literature on strategic partnerships has developed in three waves as follows: First, an empirically informed search for a conceptual core has dominated scholarly efforts. Second, the mosaic of findings on the descriptive and constitutive dimensions of the idea of strategic partnerships was intensively - but not holistically - placed in the context of individual-actor foreign policies, and functions of this emerging form of international association and engagement in bilateral, regional and global affairs. Finally, capitalizing on state-of-the-art knowledge, strategic partnerships became embedded into theoretical arguments stemming from both distinct IR mainstream and critical approaches; this, however, still fell short of developing a stand-alone theoretical framework for the analysis of strategic partnerships.

Whereas the current effort to systematize SP scholarship revolves around the three-waves perspective, the field's actual approach in the acquis académiques is much more confusing - and is certainly less straightforward and linear in reality as well. 


\subsubsection{The First Wave: 'Strategic Partnership' Building Blocks and Contesting Conceptualizations}

The idea of strategic partnership originates from the field of organizational (business and management) studies, where currently it has been fairly well established - but even today still pushes scholarship of the discipline to 'think outside the administrative box' (Elrod and Mielish, 2018, p. 617). It is no surprise that the term's migration in the early/mid-1990s to the realm of contemporary international relations and political science disciplines presented a double challenge for both students and practitioners of international relations alike.

The challenge was to think outside the administrative box and develop an IR-innate understanding of the current concept as well as look outside the paradigmatic box and therefore map the concept of strategic partnerships in international relations in both theory and practice.

\subsubsection{What's in the name? Deconstructing the idea of strategic partnership (descriptive dimension)}

The term 'strategic partnership' is a truly multifaceted concept, owing this nature not only to the different political practices worldwide but also different discursive framings and cultural-linguistic connotations. Sensu stricto, the English term 'strategic partnership' has closely corresponding linguistic versions i.a. in French (partneriat stratégique), German (strategische Partnerschaft), Spanish (asociación estratégica), Portuguese (parceria estratégica), Polish (partnerstwo strategiczne), Russian (стратегическое партнерство) and Ukrainian (стратегічне партнерство) - all pointing to the binary composition of the notion: 'partnership' plus 'strategic'.

As a matter of rule, this is where the scholarly search for the notion's ordinary meaning begins - by the term's two components being examined separately (Blanco, 2016; Michalski and Pan, 2017b, p. 18). In this deconstruction exercise, the term's principal linguistic component 'partnership' - connotes the relationship of an 'association between two or more units' and the state of 'being a partner'. This basic dictionary understanding becomes further developed in IR contexts to encompass the ideas of 'reciprocity', 'parity', 'loyalty', 'commitment', 'solidarity', as well as 'sharing' and 'commonality' of sorts (Sautenet, 2007, p. 705; Czechowska, 2013, pp. 37-8; Blanco, 2015, p. 62). Blanco's (2015, p. 62) interpretation of partnership as a philosophy, condition, process and commitment of 'sharing' perhaps most closely and succinctly describes what the term may denote in the IR/FPA context: after all, partners (must) share not only the purpose and goals of cooperation, but also the associated costs and risks. 
Today, just as three decades ago, in IR, partnership remains an elusive concept to 'realize as well as to analyze' (Milner, 1992, p. 466).

In turn, the attribute 'strategic' comes to connote two things: the relationship's political significance and its (necessary) underpinning by a master plan, that is, broadly seen strategy (thus not limiting it to the classical military understanding). Whereas the discussion of the aspect of significance does not spur much disagreement among scholarship or policymakers alike, the debate on the strategy-derived sub-component causes at least as much debate as it does in other areas of strategic analysis of IR/ FPA. The question which first invites asking is whether all partnerships that are explicitly labelled as 'strategic' can indeed be regarded as such in terms of strategic policy framework, actors' own relevance and policy outputs. The short answer would be 'no' - because not every partnership that is labelled as 'strategic' is part of an explicitly formulated strategy. This paradoxical situation is neatly captured in former European Council President Herman van Rompuy's statement: 'Until now, we have strategic partners, now we also need a strategy' (European Council, 2010).

But even those partnerships that rest on a joint strategy, or converging individual ones, may not be effectively devised to deliver their intended outcome. In this regard, Renard (2013, pp.306-8) rhetorically asked: Are all strategic partnerships truly strategic? Whether Chinese, from the European Union or the US, one of the most frequently criticized examples herein are development partnerships. Understandably, more criticism revolves around the discussion about the allegedly 'strategic' nature of partnerships that are narrowly focused, time-limited, stagnating, or those on the verge of collapse.

Therefore, the seemingly self-explicative notion of 'strategic partnership' does not lend itself well to the deconstruction exercise, therefore bringing more confusion than clarity and precision to what it really connotes. Simple observations of the practice of strategic partnerships worldwide only confirm the careful analytical assumption: it is not that simple. Consequently, a practice- and theory-informed definition of conceptual precision has long been overdue.

\subsubsection{An 'unidentified political object'? Contesting concepts and misconceptions of strategic partnerships (constitutive dimension)}

Strategic partnerships are an evolving and truly evasive phenomenon, which until now has not allowed the scholarly community to come up with an at least satisfactory - if not consensual - definition. Strategic partnerships come to either encompass many things at once or appear as an empty-shell idea, or as a 'bastard' of the parental concept of 'alliance' in IR. In many cases, this concept appears as a UPO - a sort of 
'unidentified political object', as was once eloquently and light-heartedly stated by the European Commission's visionary President, Jacques Delors, to refer to the evolving nature and unfinished future of the then-European Communities (Delors, 1985).

Normally, the first steps in conceptual navigation have entailed a scholarly effort to distinguish the novel idea from other interchangeable, similar or distantly related concepts. It has been established that, whereas marking a clear departure from the most similar ideas of 'alliance', strategic partnerships also differ from 'international regimes', 'security communities', 'ad hoc groupings' ('coalitions'), and other forms of 'special relations' (Tyushka, 2010; Wilkins, 2008).

Second, minimalistic conceptions of strategic partnership were devised, that is, to analytically frame some of the early writings addressing the phenomenon in practice. Assuming a structural-functionalist view, Lessa (1998) defined strategic partnerships as "priority political and economic relations, reciprocally compensating, established on the basis of an accumulation of bilateral relations of a universal nature' (p. 31; 2010, p. 119). Whereas Emerson et al.'s (2001) agential perspective of the notion defines 'strategic partnership' as a particular type of relationship that 'involves two actors that are powerful and capable of taking strategic action together' (p. 45).

In the 2000 s, when the idea and practice of strategic partnerships proliferated, there was still little understanding and agreement as to what was at stake. Notably, the policymaking community also remained far from specific upon this. Neither in 2003, when strategic partnerships entered the EU lexicon, nor in 2010, when it became one of the Union's foreign policy principles, did the idea become specified: 'Strategic partnerships are a political category that no EU document or statement clearly defines' (Grevi, 2010, p. 2). To our knowledge, this situation is not confined to the EU's case alone - in most of the studied cases, strategic partnerships remain a 'UPO', the only exception being perhaps NATO SPs that are narrow in scope, clearly defined, systematized and anchored in the Alliance's doctrine.

This imprecision of the political category, its ambiguous rhetorical use and the varying international practices have left the scholarly community grappling with a mosaic of strategic partnership manifestations and 'extracting' their observable features.

Third, accounts blossomed in literature that mainly sought to outline the conceptual core and contours of strategic partnership based on what were usually single-case empirical observations. Not surprisingly, the empirically informed analysis of strategic partnerships, which differed in form, purpose, size or function, amounted to a plethora of tailor-made 
conceptions of the notion - sometimes (partially) overlapping but always contesting, especially along the lines of English vs. non-English writings (cf. Table 1.1).

Rare exceptions perhaps include Wilkins's (2008) conceptual framework and his 'organizational' analytical model of strategic partnerships, which finds its use by other authors (Adelle and Kotsopoulos, 2017; Geldenhuys, 2015 ) and there is Nadkarni's (2010, pp. 48-9) succinct and most frequently referenced conception of the notion.

Following Wilkins (2008), a strategic partnership exhibits the following four constitutive features: First, SPs are 'organized around a general (security) purpose known as a system principle (such as championship of a multi-polar world), rather than a specific task, such as deterring or fighting a hostile state' (pp. 360-1). Second, SPs are 'primarily goal-driven rather than threat-driven arrangements'. Third, SPs 'tend to be informal in nature and entail low commitment costs, rather than being explicitly formalized in a specific alliance treaty that binds the participants to rigid courses of action'. Finally, among SPs, 'economic exchange appears salient among "functional areas" of cooperation and is one of the key drivers of the partnership, alongside security concerns'. Thereby, the author draws the lines of differentiation of SPs from alliances and coalitions, which admittedly share 'some congruities' with strategic partnerships but neither of which 'truly captures the distinctiveness of a strategic partnership' (Wilkins, 2008, p. 361).

Nadkarni's (2010) catalogue of six SP constitutive features is one of the most referred to conceptualizations of the notion:

[Strategic partnership] relationships generally contain several common elements forging links between countries that are neither allies nor adversaries, but which share a range of both common and divergent interests: (1) they are formalized in multiple written declarations, statements, agreements, and memoranda of understandings that outline clear policy objectives and attempt to build upon and deepen multifaceted ties; (2) they create formal institutional links at various governmental and non-governmental levels, generating multiple interactive channels at the levels of Track I (official) and Track II (people-to-people) diplomacy; (3) they set up a mechanism for summit meetings between top leaders that are held alternately in the capital cities of the two countries, with more frequent meetings at the sub-ministerial and bureaucratic levels where officials explore common interests or concerns, often in joint task forces established to address specific issues; (4) they work to develop ties between respective military establishments through joint military exercises, having naval vessels make ports of call, and working on confidence building measures; (5) they seek to establish a stronger economic relationship; and finally, (6) they attempt to foster greater awareness of each other's culture through youth exchanges and cultural fairs. (pp. 48-9) 


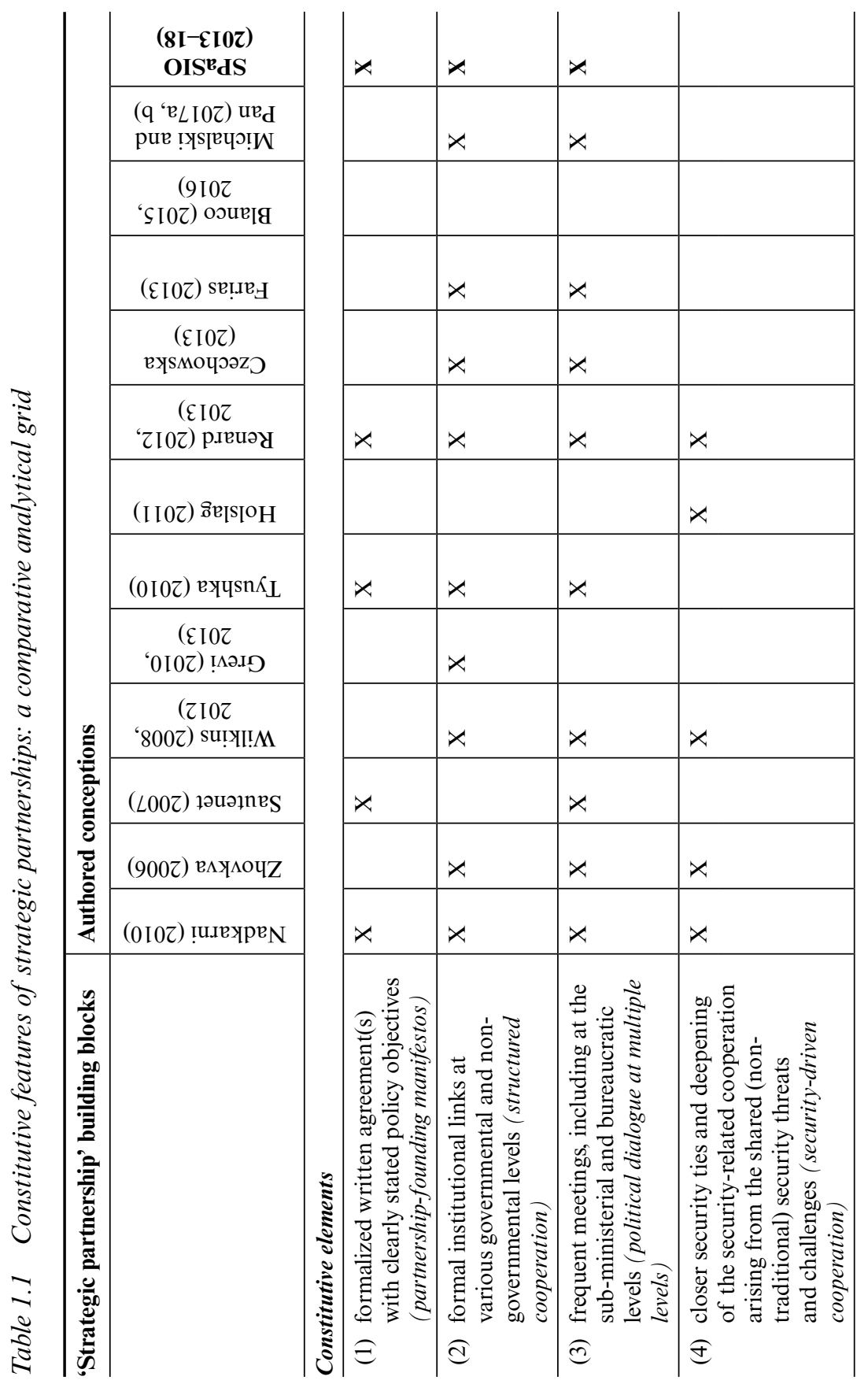




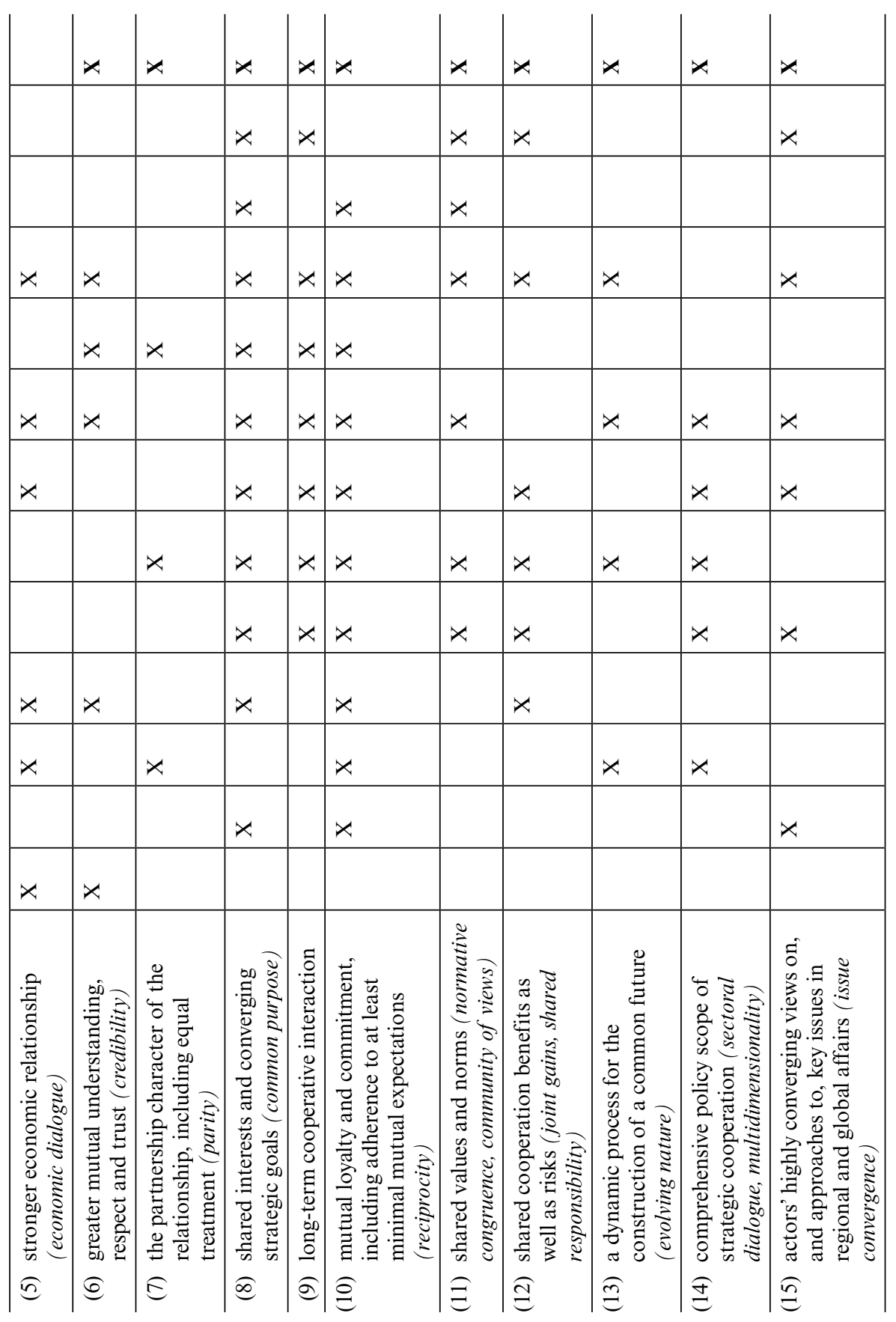




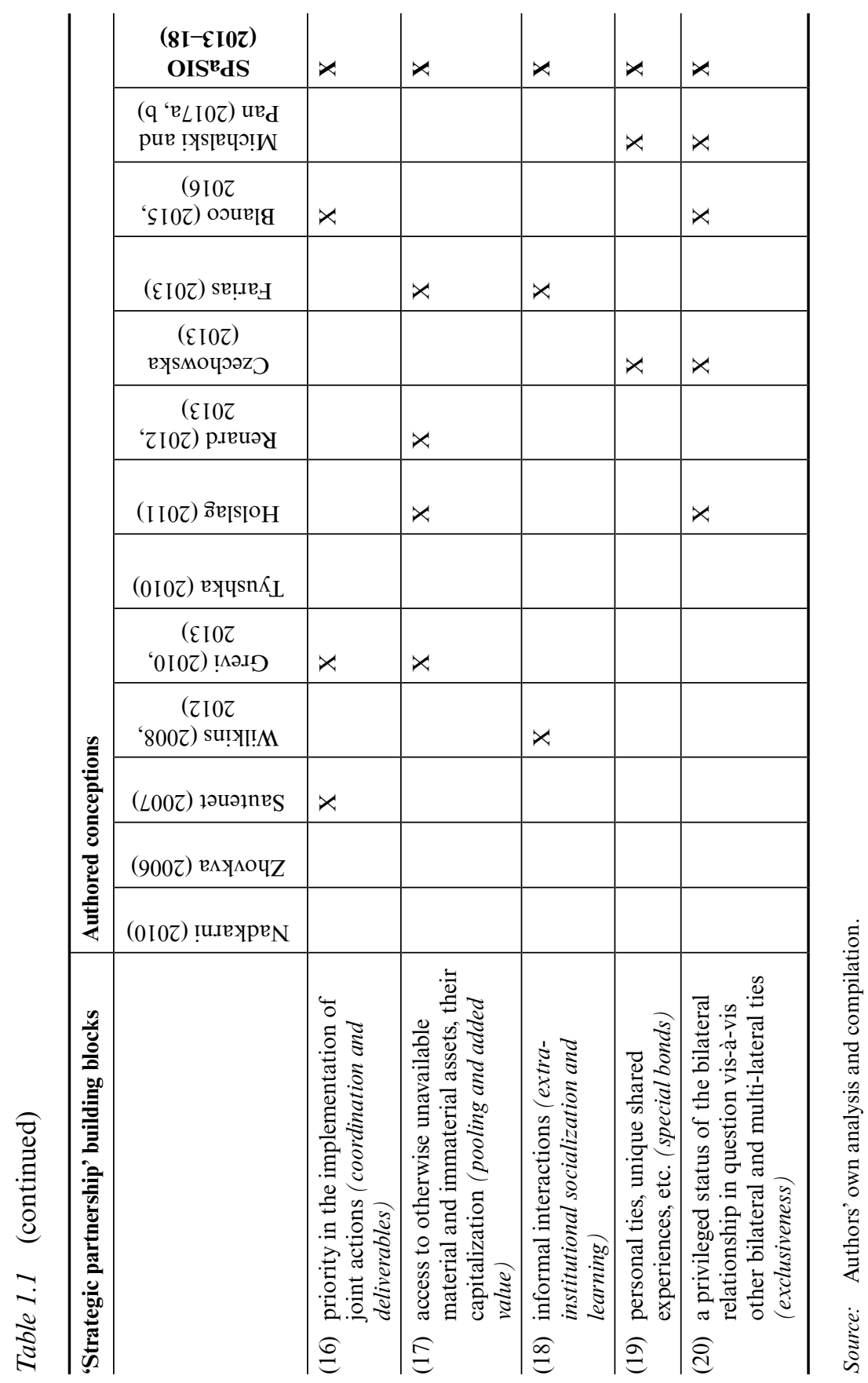


Developed from Nadkarni's observations of the specific three partnerships (Sino-Russian, Indo-Russian and Sino-Indian SPs), this set of determinants - as many other subsequently produced conceptualizations evidently cannot claim universal and unconditional applicability, especially as regards the requirement of military cooperation.

Similarly, Holslag developed a catalogue of five main SP features that include the 'identified common interests and expectations' as well as the quality of SPs being 'formulated for the long term'; moreover, SPs 'need to be multidimensional and operationalized in the economic, political and military areas of interest', as well as needing to 'have a global range'; finally, and importantly, 'the incentives should be of such a nature that they cannot be achieved without partnership and serve to distinguish it from other relationships'. Symptomatically, in a firm belief that 'strategic partnerships have more to do with form than with purpose' (Holslag, 2011, p. 295), the author, similar to Nadkarni (2010), presented an organizational and structural take on the notion - however, the two accounts only tangentially overlap in their assessments of what constitutes a strategic partnership (Table 1.1).

Drawing on Nadkarni's (2010, pp.48-9) description of SP 'technical elements', Renard (2013) complements the list with the following features that "make a partnership truly "strategic":

First, a strategic partnership must be comprehensive, in order to allow linkages and tradeoffs between various policies. Second, it must be built upon reciprocity, short of which it cannot be deemed a partnership at all. Third, a strategic partnership has a strong empathic dimension, which means that both partners share a common understanding of their mutual values and objectives. Fourth, a strategic partnership must be oriented towards the long term, which is to say that it is not put into question by casual disputes. Finally, a strategic partnership must go beyond bilateral issues to tackle (with the potential to solve) regional and global challenges, because that is its true raison d'être. (pp. 303-4)

Following similar epistemological paths, non-English scholarship has sought to identify the most salient and notion-determining elements of strategic partnerships. According to the Ukrainian scholar Zhovkva (2005), strategic partnerships are a special instrument of the state's foreign policy toolkit, which the state uses to coordinate its actions on the international arena with other states. The author developed a finite catalogue of SP determining elements (p. 10) that include: (1) 'similar interests among partners, and, ideally, their convergence'; (2) 'a high degree of convergence of views and approaches to key issues of regional and/or global politics'; (3) 'the willingness to reconcile one's own interests with the interests of the strategic partner or the willingness to make decisions in support of the 
partner on the international stage, even if such actions are not necessarily beneficial for one's own good'; (4) 'common challenges and threats (such as organized crime, illegal migration, arms and drug smuggling, aggressive separatism, terrorism) - and the determination to work together in order to overcome them'; (5) 'a mechanism for implementing the strategic partnership', or 'the willingness and potential to create such' (Zhovkva, 2006). Similar though somewhat more extensive elaborations were presented by Tyushka (2010), Farias (2013) and Czechowska (2013).

Thus, in the absence of official doctrinal definitions of strategic partnerships, and in view of their variance in substance and form from context to context, by now, state of art in the field is best characterized as that of a 'double constructivism': in addition to the much-shared constructivist understanding that strategic partnerships are 'what states make of it' (Holslag (2011, p. 295), the first among authors to apply Wendt's logic to SPs) - strategic partnerships have also proven to be "what the [scholars] make of it'.

Distinct in their cast of analytical perspectives (structural-functional, process-oriented, agential, or interactional), the field-impacting conceptualizations still manifest some modest degree of congruence. As the comparative outlook on authored conceptions of SP reveals, the most frequently posited determinants are: formal institutional links at multiple levels, regular and multi-levelled contacts, shared interests and converging strategic goals, mutual loyalty and commitment, as well as the long-term design and functioning of the relationship in question. The second-order variables identified by the authors include: the formal design of the partnership; a greater mutual understanding, respect and trust; actors' converging views on international and regional issues and the system as such; their closer interaction in security affairs and the economic area, including possibly broad coverage of other areas of cooperation; finally, shared (sic! not necessarily common or identical) values and norms are said to cement strategic relationships more strongly than when they were not given or featured.

Understandably, the frequency of the authors' referrals to some variables as compared to others can tell something about an emerging consensus in the field. However, this should not be taken at face value as little to no research has been conducted to verify the validity of the authors' claims about the SP-constitutive elements. In other words, little is known as to why the afore-listed 20 elements (which, in fact, do not represent an exhaustive list!) were incorporated into the SP conceptual frameworks, and which ones matter more than others. The SPaSIO project, therefore, sought to face the challenge of testing the aforementioned assumptions, thus contributing to closing the current gap in the literature and provide 
a theoretically informed and empirically verified account of strategic partnerships in international relations.

With no aim or promise to deliver an all-encompassing definition of the term (a pointless and a daunting task to undertake!), our effort is directed instead towards providing a clear and 'tested' analytical model with a list of generally feasible variables. This should also help mitigate the many misconceptions of the SP idea, most of which are related, in one way or another, to the issue of 'labelling'. Grevi (2010) outlines the problem with labelling by positing that 'partnerships do not become strategic by virtue of defining them as such' (p. 2). One may extend the argument by claiming that non-defining the partnership as strategic, or non-labelling the relationship as a strategic partnership expressis verbis, does not prevent a relationship in question manifesting as a strategic partnership. Thus, both analysts and practitioners of international relations are faced with a confusing variety of situations that are associated with explicit labelling, non-labelling or mislabelling a type of relationship in question as a strategic partnership.

On the one hand, relations between actors may be explicitly labelled by the actors themselves as a strategic partnership, whereas in reality such relationship might not manifest much partnership, strategic relevance, or either. The fallacy of such mislabelling might have its roots in actors' perception of SPs as a trendy image-relevant FP tool which they need to have in their arsenal or simply a desire to boost the relationship in question to such a level in the future, or at least not exclude such a course of action. NATO or the EU's SP partnerships with Russia are certainly cases in question in this regard.

On the other hand, relations that in their form and purpose correspond with the theoretical and empirical understandings of what a strategic partnership is might remain unnamed by the actors themselves as such - or at all. The reasons for non-labelling are too highly contextual and specific to be generalized. For example, in the case of EU-Australia strategic relations, Murray (2016) hypothesizes on the 'burden of memory' as an obstacle for both partners, and mainly the EU, to publicly designate their relationship as a 'strategic partnership' (pp. 174-6).

However, the practices of labelling relations as strategic partnerships also feature some pitfalls - especially where strategic partnership is not comprehensively embedded as an actor's foreign policy principle but applied sporadically or eclectically. This creates an inclusion/exclusion issue as well as problems with identifying strategic and ordinary lines of foreign-political interaction.

An example would be the EU's partnership policy framework that explicitly lists only ten international actors as the European Union's 
strategic partners, thus by definition excluding the UfM (Union for the Mediterranean) or EaP (Eastern Partnership) countries and the EU's relations with them from this paradigm. Another example of complex labelling of an evolving partnership relationship is the designation of the EU-China SP in the EU's official jargon - 'from constructive partnership to comprehensive partnership and then to today's comprehensive strategic partnership' (Yang, 2007). The system of China's diversified SPs across the globe - and respective labelling of multi-layered SPs - presents yet another example of an inflated discursive recourse to the SP concept (Oviedo, 2006).

Including or excluding the clusters of mislabelled, non-labelled or indeed explicitly labelled 'strategic partnerships' bears direct implications for the design of strategic partnerships' analytical framework and the scope of conceptualization. Envall and Hall (2016) adopt a formalistic approach by regarding strategic partnerships as such only if they are 'referred to as such in inter-state agreements, leaving aside the question of whether strategic partnerships can or do exist in undeclared forms or in the absence of a formal agreement creating one' (p. 88).

Such a formalistic approach is in fact even more entrenched than it seems, for it leads to the exclusion of strategic partnerships in practice that are referred to in inter-state agreements, for instance, 'development partnerships', 'association relations' or simply 'partnerships'. Of course, the other side of the coin is overstretching the concept, should the 'anything-goes' approach be adopted and any bilateral form of interaction be included herein. Clearly, a greater theoretical embedding of the term is needed to devise an appropriate method and sample of analysis.

\subsubsection{The Second Wave: Strategic Partnership Typologies and Functional Explanations}

Within the so-called 'second wave' in the study of strategic partnerships, the scholarly focus shifted towards distilling strategic partnerships from within (i.e. in contrast to non-strategic partnerships and non-partnership strategic relations), and classifying strategic partnerships by their substance and, above all, purpose, thus creating multiple hierarchical typologies and advancing functional explanations of what role SPs perform in actors' foreign policy doctrines and practices.

In addition to widening research on this political phenomenon, the structural-functional accounts of SPs proliferated intending to save the idea of strategic partnership from conceptual devaluation and political irrelevance or from shallowness, a trend that developed as a side-effect of the inflated use of the term in politics and academia. Renard eloquently 
outlined the analytical and political dilemmas surrounding the concept's increased use and especially misuse: 'With no clear list of constitutive elements [of partners and priority partnerships], no real substance and no purpose, strategic partnerships appear like an uncertain fleet of empty vessels sailing in the troubled water of multipolarity with no course to follow' (Renard, 2011a). It is the search for substance and purpose of strategic partnerships that framed the critical analytical effort within the 'second wave'.

\subsubsection{The relevance and effectiveness of strategic partnerships in foreign policy (performative dimension)}

The main research problem for studies focusing on the substantiality of strategic partnerships has been linked to the inherent degreeism of SP relevance and effectiveness (performative dimension), i.e. the degree to which the SP in question could satisfy the requirements of being strategic and a partnership at the same time. The distinction between substantive (Czechowska, 2013, pp. 32-3, 45-81) - including the related ideas of real (Renard, 2011b), genuine (Lo, 2008, pp.40-1), effective (Grevi, 2010) and true (Renard, 2013, pp.312-13) - strategic partnerships, on one hand, and other forms of partner-like cooperation or strategic non-partner relations, on the other, has become the leitmotif of individual scholarly and analytical policy inquiries. The genuineness and relevance (performance, effectiveness) of a relationship in question serve as main markers of differentiation (however, no real measuring of the mentioned qualities informed the aforementioned research programmes).

On the relevance side, importantly, strategic partnerships not only are sustained but they deliver (Grevi, 2010, p. 5) - and do so well 'beyond the bilateral confines', thus being effectively instrumentalized for the pursuit of partners' broader (regional and global) interests (Renard, 2011b, p. 97).

Of no lesser significance is 'parties regard [their strategic partnership] as essential to achieve their basic goals' (Grevi, 2010, p. 3), thus partnership being their best or only alternative to their own Alleingang, that is, solitary action. Renard's (2012, pp. 2-6) ten guiding principles on turning strategic partnerships into an effective foreign policy instrument suggest that in order for them to be relevant, strategic partnerships should address 'strategic issues' (thus go beyond the first economic layer of interaction) and grow out of 'cooperation on concrete issues'; they also must be sustained at the highest level of strategic interaction (summits) and expand beyond the confines (both in terms of agenda and actual political reach) of bilateral relations.

As regards the check for genuineness, the main concern is how to distinguish 'the genuinely strategic relationship from its facsimile' (Lo, 
2008, p. 41). In his book on the Sino-Russian 'axis of convenience', Lo (2008) laments that during the early 1990s, Russian leadership designated as a strategic partnership 'every relationship of significance and [...] many that were not'. This move allegedly had a clear political purpose - to create legitimacy for Russia's foreign-political claims and (inter)actions, 'often serving to mask a lack of content with the illusion of significance' (p. 40).

Rather than substantial, 'strategic partnerships may also simply be a rhetorical device used by diplomats to help them around the rough edges of shifting global politics,' Kay (2000, p. 17) put forth in his debate-opening article 'What is a strategic partnership?' Along with the teleological rationale and form, the performative level as well codetermines the degree of substantiality (or, respectively, shallowness) of strategic partnerships.

Maher (2016) posits that 'despite steadily improving relations, the past decade has also shown that the EU and China remain divided over core political values, geopolitical interests and priorities, and conceptions of world order', wherefore the depth and scope of the EU-Chinese SP has become limited to the extent that their relationships 'are today, and are likely to remain, contested, uneven, and - apart from trade and investment - shallow, and that they embody a limited rather than a strategic partnership' (pp. 959, 960).

In her causal conditional reasoning on distinguishing strategic partnerships from non-strategic partnerships, Czechowska (2013, pp.45-81) develops a matrix of four necessity conditions and three sufficiency conditions. For a relationship to qualify as a form of strategic partnership, it needs to necessarily demonstrate: (1) the partnership character of bilateral interaction (understood as a freewill-based relationship that is characterized by mutual respect and consideration, parity and loyalty), (2) the (minimal necessary) convergence of strategic goals, as confirmed in official discourses of both partners; (3) the shared understanding of mutual gains and of the fact that their individually pursued goals would not be achieved as effectively when acting alone; (4) the long-term orientation of cooperation, including the progressive deepening of the strategic interaction (Czechowska, 2013, pp.79-80). In turn, substantive strategic partnerships should also be able to qualify in terms of the following three sufficiency conditions: (5) the manifested privileged status and practice of relationship, including through the higher (than usual) intensity of interactions (meetings at multiple executive and bureaucratic levels) and the privileged economic links; (6) developed cooperation structures at various levels of interaction - from governmental to cultural and societal; (7) a truly cooperative spirit that allows for smooth problem-solving, not least due to the resolve in solving the problem rather than problematizing 
(in high-level corridors) sporadically occurring issues of sorts, including the ones stemming from shared historical experiences (Czechowska, 2013, pp. 80-81).

The problem with this and other featured qualitative approaches that distinguish between substantive and non-substantive strategic partnerships lies in the missing measurable grid therein, and thus an associated high level of subjectivity in assessing how convergent should strategic goals and interests be, how many structures of cooperation qualify for sufficiency, etc. Lo (2008) emphasizes that '[i]t is important not to set the bar either too high or too low':

It is improbable, for example, that partners will agree on every issue, all the time. [. . .] On the other hand, it is reasonable to expect a certain shared vision, both of the world in general and of the partners' respective roles within it. Defining a relationship as strategic implies a long-term reciprocal commitment, one resilient enough to withstand occasional setbacks and misunderstandings. Although there is scope for tactical opportunism, this remains an unstable basis for constructive engagement and cannot be overplayed. Similarly, instrumental considerations - the use of partnership to exercise leverage on third parties should not exercise a disproportionate influence. For in that event the bilateral relationship would become overly susceptible to changes in the external environment. Ultimately, a bona fide strategic partnership is predicated on a broad consistency of purpose. It succeeds or fails to the extent that both sides are able to identify lasting common interests and to translate these into far-reaching, substantive cooperation. (p. 41)

In light of the aforementioned, the question is, what is the ideal point, the point of departure in setting the bar neither too high nor too low, to paraphrase the afore-quoted author. Regrettably, none of the qualitative studies, which have dominated research on strategic partnerships so far, have been able to provide an answer to that question. And that being so, only ex-post evaluations of the phenomenon appear possible, which certainly limits the possibilities for ex ante assessments of ongoing developments within functioning strategic partnerships, as well as limits the predictive capacity and explanatory value of the claims so far advanced. The SPaSIO project is aimed at closing this gap as well and providing a tested measuring grid for the assessment of strategic partnerships' substantiality.

\subsubsection{The purpose and functions of strategic partnerships in foreign policy (functional dimension)}

Even before a potential partner is identified and the partnership is conceived, a fundamental foreign policy question each actor needs to answer is: why a strategic partnership? An inside-out perspective on purposes and functions of this foreign policy tool is crucial for understanding why the 
strategic partnerships phenomenon proliferated so intensively and what it holds for the future.

Growing out of cooperation on specific and/or strategic issues, strategic partnerships usually serve broader goals and purposes. Our empirical studies within the SPaSIO project strongly confirm Grevi's (2013) contention that ' $[r]$ eal-life strategic partnerships are multi-purpose ones, pursuing both bilateral and multilateral objectives and shifting focus across these and other dimensions of the relationship in a fairly pragmatic way' (p. 163). The purpose of each partnership derives from the unique blend of the partnering actors' 'motives to achieve material, reputational, and ideational interests which in their turn originate from their perceptions of identity, roles, and rightful position in the international system on the one hand, and how they rate their vulnerability, vis-à-vis international interdependence on the other' (Michalski and Pan, 2017b, p. 26).

Until now, scholarly discussion of purpose and functions of strategic partnerships has been limited to a handful of seminal accounts, including by Zhovkva (2006), Grevi (2013), Blanco (2015, pp. 79-100; 2016), Bang (2017) and Michalski and Pan (2017b, pp.26-31). In most cases, the functional explanations overlap, which is a good sign of an emerging scholarly consensus as regards the role and purpose of the notion in actors' foreign policies, their bilateral relations and wider international engagements.

Going into detail of every approach would exceed the scope and rationale of the current effort, thus what follows is an effort to systematize and blend what we regard as the most perfectly compatible and most accentuated accounts: On one hand, Grevi's (2013) explanations on (a) reflexive, (b) relational and (c) structural functions of strategic partnerships, on the other, Michalski and Pan's assessments (2017b, pp.26-31) of strategic partnerships' aims and functions from (a) individual ('ego'), (b) bilateral (interrelational) and (c) systemic (international) perspectives.

First, at the level of individual actor, strategic partnerships fulfil reflexive (self-assertive) (Grevi, 2013, pp.163-4), or status-enhancing (Michalski and Pan, 2017b, pp.30-31) functions. The reflexive function of strategic partnerships entails both discursive (Bang, 2017; Blanco, 2016) and practical (Michalski and Pan, 2017b, pp.30-31) modes of self-assertion of an actor as a partner, as an international player and, sometimes, also as a pole or node of power in an evolving and polycentric international system. Michalski and Pan (2017b, p. 30) underline that the 'ego'-related function of strategic partnerships is to provide 'arenas for social engagement in which each partner state can project and reinforce its respective self-conceptions as international actors'. For instance, Blanco (2016, p. 37) stipulates that the EU's discursive use of strategic partnerships serves 
'to advance a normative foreign policy', thus further consolidating the Union's image and status as normative power in international affairs.

Remarkably, strategic partnerships present an opportunity for statusenhancement of both globally influential and less powerful strategic actors:

The status-enhancing quality of strategic partnerships is applicable both to global powers - as partnerships provide them with structures to influence the global agenda and prevailing worldviews, and ultimately shape the international order - as well as to lesser actors for whom the engagement with globally significant powers gives them access to international politics and opportunities to influence issues that lie close to their core interests. (Michalski and Pan, 2017b, p. 30)

Thereby, the modes of action range from 'reflexive learning' and 'introspective identity formulation' to 'internal re-negotiation of identity' (Michalski and Pan, 2017b, p.30). Vieira's (2016, pp.134-6) study on recalibrating of the EU's 'self', 'we' and 'other' within the EaP framework provides an illuminating example. Thus, strategic partnerships are conducive to the enhancement of status and strategic acting of the partners concerned.

Second, at the level of bilateral interaction, strategic partnerships fulfil the relational (management) (Grevi, 2013, pp. 164-6) function. This function is associated with the management of bilateral relations 'in direct pursuit of the respective interests of the two parties'. Thereby, economics is said to remain 'the backbone of [many] partnerships' agendas' (Grevi, 2013, p. 164).

However, the scope and depth of bilateral engagement usually extends beyond the economics first principle, not least because privileged partnerships 'enable structured engagement, exchange of information, platforms for bilateral problem-solving, and preparation for multilateral governance of thorny international issues - all aspects that enhance an actor's ability to fulfil foreign policy objectives and realize foreign policy roles' (Michalski and Pan, 2017b, p. 28).

Analysing the competitive role-playing which occurs within the EUChina strategic partnership, Michalski and Pan (2017a, p. 611) advance an argument that both the European Union and China engage in such structurally framed and competitive role-playing in order to 'enhance their position and status as global actors and to seek recognition of their international roles'. Thereby, the modes of interaction take the form of 'strategic role-playing', including via 'communicative action and rhetorical persuasion', 'socialization' and 'learning' (Michalski and Pan, 2017b, pp. 29-30).

Third, at the international level, strategic partnerships feature as vehicles of social interaction, since structured bilateral relationships are more likely 
to 'bolster interstate engagement' (Michalski and Pan, 2017b, pp. 27-8). The structural function of strategic partnerships (Grevi, 2013, pp. 166-9) extends beyond the effort in structuring the bilateral interaction in question to also cover the areas of wider mini-lateral and multi-lateral international engagements.

Grevi (2013) hypothesizes that effective strategic partnerships actually 'seek to make bilateral dealings not only compatible with but also conducive to stronger multilateral cooperation' (p. 166; see also Grevi, 2010, pp.11-12). Similar views are presented by Renard (2016b). Exploring the place of strategic partnerships in various lateralisms (i.e. interrelationships between bilateral, multi-lateral, regional and mini-lateral interactions), Renard (2016b) concludes that in practice, the axiom 'partnerships for effective multilateralism' may not always work - what is more, 'bilateralism, in the form of strategic partnerships, can [also] undermine or substitute regionalism and multilateralism' (p. 30). However, in most cases, the author hypothesizes further bilateral partnerships do complement and reinforce regional or multi-lateral approaches, for instance, in the case of EU climate change negotiations or global security issues (notably, terrorism and nonproliferation). Thus, by providing structure to inter-state interactions, first and foremost on geopolitical hotspots, strategic partnerships can reinforce multi-lateral engagement in strategic affairs, enhance global governance, and shape the international system into a dense web of bilateralism.

\subsubsection{The Third Wave: Embedding 'Strategic Partnerships' into Existing IR Theories and Approaches}

The rapid proliferation, highly contextual and fluctuating nature of strategic partnerships has rendered the task of defining and explaining them, including their systemic effects, extremely difficult. Even the most recent review of contending concepts and approaches to the study of strategic partnerships confirms that the IR/FPA scholarship still has not developed a full-fledged theory of strategic partnerships (Ferreira-Pereira and Vieira, 2016). However, important steps have been made to distil the concept of 'strategic partnerships' by distinguishing it from related ideas such as 'alliance', 'coalition' or 'security community'.

\subsubsection{Organizational studies:}

from business alliances to public-private partnerships to international (political, economic and legal) governance structures

The idea of strategic partnerships in IR resonates with a definition from organizational and international business studies. Herein, a strategic partnership is usually understood as a formal strategic alliance between mainly 
two commercial enterprises, formalized - as a matter of rule - by one or more business contracts setting out the goals and procedures of joint pursuit of business activities.

Czechowska's (2013) conceptual framework on SPs is derived from business studies and practical understandings of the notion. In comparative government and politics, public-private partnerships (PPPs) represent the related analytical category. Iankova (2009) uses the PPP logic in her analysis of strategic partnerships between business and government in the context of accession to the EU of post-communist European states.

In international political economy, both the original meaning of strategic partnerships as 'business alliances' and its derived meaning of a political 'inter-state alliance' do uniquely intersect (Watson, 2001). Herein, strategic partnerships play a role due to the 'fundamental relationship between economics and politics that an alliance represents', not least because 'the pattern of international trade tends to complement a state's strategic political partnerships - in other words, "trade follows the flag"" (Watson, 2001, p. 1488).

The arrival of a strategic partnerships research agenda into IR/FPA domains usually occurs in the interdisciplinary approach of international organization studies. Both system and network analysis, and governance studies, including legal governance, are some of the most frequently used perspectives to study strategic partnerships.

The pioneering of this field belongs to Wilkins (2008), who first developed the organizational approach, which 'looks at several organizational dimensions through a division into three sequential phases of development across a collaboration continuum: formation, implementation, and evaluation' (p. 363). This analytical framework was promisingly linked with the author's original ontological accounts regarding strategic partnerships as a distinct archetype with the taxonomy of 'alignment' rather than 'alliance', 'coalition', 'security community' or 'international regime'.

Governance literature further expanded the notion's analytical scope by applying the logic of 'networks', 'governance structures' and 'socialization' to explain the ways in which strategic partnerships form and function. Bache (2010) disentangles the facets of partnership as a long-standing European Union policy instrument within the system of multi-level governance. Grevi (2013) casts a view of how the SP web has placed the EU on the international stage and enhanced global governance structures, thus capitalizing on the 'economics first' argument.

In the framework of his study of the EU-China strategic partnership, Sautenet (2007) develops a synergetic perspective on the former as a form of economic and legal governance. He contends that as such, strategic partnership needs to live up to at least three characteristics: 'adherence by 
the partners to at least a minimum of common benchmarks, equal relations between the partners and a dynamic process for the construction of a common future' (p. 705).

Blending the socio-legal perspective with network analysis, Slobodchikoff and Tandon (2017) succeed in conceptualizing 'groups of treaties as institutions' and promisingly analyse the Indo-Russian strategic partnership through its 'treaty networks' (p. 166). Michalski and Pan (2017a) elaborate on how strategic partnership structures are conducive to role-playing (thus re-constitution of actors' identities), as well as socialization and learning (thus providing for the interaction-driven convergence).

\subsubsection{Historical institutionalism: strategic partnerships in the confines of path dependency}

Even though strategic partnerships are a relatively new phenomenon that emerged with the beginning of the post-bipolar era in IR, state and IO actors who enter into this relationship are certainly much 'older' than the phenomenon at stake. Therefore, actors' historical memory matters for strategic partnerships to get forged and functioning - there goes the main historical institutionalist argument. There are certainly actors for whom history matters more than it does to others.

In the study of Chinese SP's, historical institutionalism offers crucial insights since it 'analyzes macro contexts and hypothesizes about the combined effects of institutions and processes rather than examining just one institution or process at a time' (Wang, 2017, p.270). In his analysis of the Sino-Swiss strategic partnership as a model case for China-Europe relations, Wang posits that the positive development of the Sino-Swiss partnership owes its dynamics to a long history of smooth interaction (2017, pp. 271-2).

Should the history of interaction or institutional memory of the relationship feature less than positive dynamics, especially at 'critical junctures', the historical institutionalist argument would suggest modest to scant possibilities for forging and substantiation of a strategic partnership. 'Path dependency' may compel states to follow adversarial or at best inert (indifferent) patterns of interaction. Gilson (2016) discusses the pitfalls of the path of dependency in the inertial development of the EU-Japan SP, which is 'confined' by the early institutional framework of 1991 and became outdated with the parties' lines about one another's relevance. As a consequence, ghosts of the past may prevent strategic partnerships from unfolding their full potential and creating meaningful structures of bilateral association and engagement. 


\subsubsection{Realism:}

\section{strategic partnerships in the shadow of the alliance}

Rather expectedly, the most popular scholarly perspective on strategic partnerships is realism - and to be more precise, the neoclassical and structural realist strands of theorizing. It is also emblematic that the only consensus in the study of the field of strategic partnerships is a consensus on distinguishing strategic partnerships from alliances, that is, one of the main recognized realist categories.

Wilkins (2008, pp. 359-61) was the first to present strategic partnerships as 'a new form of alignment'. Embracing the realist 'balance of threat' argument, Powell posits that alignment is basically about picking sides: 'When one state threatens another, a third state has at least three options. It can align with the threatened state, align with the state making the threat, or try to avoid taking part in the conflict by waiting' (1999, p. 149).

This understanding of alignment is well-informed by a history of bandwagoning (weaker with stronger states), soft balancing (weaker against stronger states) or practising the neutrality of international politics prevalent in the nineteenth and much of the twentieth century. However, dated political methodology may not live up to twenty-first century IR, where direct state-to-state threats and confrontations are less common, whereas multifaceted challenges of a transnational character, which do not necessarily or wilfully originate from other states, proliferate tremendously. The multi-actor world, including the now powerful international organizations and non-state actors, alongside increasing interdependence, additionally feature as salient correlates of a new international-political reality. To reckon with this, new modes of alignment are emerging.

Alignment of past centuries might therefore not necessarily be what foreign-political practices of association and alignment mean in today's politics - even if terminologically identical concepts still find usage. For instance, Gratius's (2012) analysis of a spat in the once close EU-Brazil relationship embraces the logic of 'balancing and bandwagoning' to explain strategic divergence and competition between the two actors on the international stage. In a similar vein, Nadkarni (2010) elaborates on 'balancing without alliances' in Asia and Eurasia, by focusing on the Sino-Russian, Indo-Russian and Sino-Indian SPs as enabling structural frameworks for such a balancing exercise.

\subsubsection{Constructivism:}

strategic partnerships as 'what the states make of them'

Strategic partnerships are inherently social constructions - i.e. structures of strategic interaction and commitment that allow states and international organizations alike to pursue their foreign-political interests and goals 
vis-à-vis one another and other actors in the international system. Thereby, they help mitigate the nasty consequences of international anarchy (either by expanding bilateral networks of cooperation, or containment partnerships), promote an international system configuration which better suits their worldviews and normative orientations, as well as allow actors to pursue their individual image- or status-related goals in world affairs. Truly interactional and re-constitutive, strategic partnerships can mean various things for various actors in various moments of time and contexts.

In view of this, any 'fixed meaning' of strategic partnerships appears implausible. Blanco's (2015) main concern with the search for a 'stable' and universally acceptable definition of 'strategic partnership' is indeed that it is associated with the expectation of a fixed meaning, whereas, in fact, the partner perceptions, understandings and practices shape the term in distinct ways. This approach inevitably echoes the main constructivist maxim, thus presupposing that strategic partnerships are what states make of them. Therefore, discursive as well as policy practices do matter.

Blanco (2016) and Bang (2017) applied linguistic approaches to study the functions of the EU's and Chinese strategic partnerships, respectively. Taneja (2010), and Michalski and Pan (2017b) focus instead on the ideas and norms that partners share, as well as the levels of such normative congruence as manifestations of the SP development. The argument is being made that the competing worldviews influence actors' perceptions and pursuit of the organizational principles and governing norms that underwrite the contemporary international system. How actors view one another, the international system and their engagement within it, directly translates into what they will make from their strategic partnership.

\subsubsection{Critical security studies:} strategic partnerships as new security practices and avenues of
security governance

The proponents of the critical security approach towards strategic partnerships strongly draw on the framework ideas of international practices and security governance. Following Adler and Pouliot (2011, pp.4-8), 'international practices' are understood as 'socially meaningful patterns of action', that is, iterated patterns of actor behaviour and performance, that are informed by shared 'background knowledge' about their purpose, function and meaning.

Envall and Hall (2016, p.88) argue that strategic partnerships are best understood as "a new "security practice"" and that "they signal the emergence of new forms of "security governance". In Asia, the latter is understood as a form of security management by the involvement of both state and non-state actors, (formal and informal) institutions, (informal) 
understandings and (formalized) legal norms and rules as well as various new techniques of governance (such as networked governance).

Developing his thesis of strategic partnerships as 'a new form of alignment' (Wilkins, 2008, p. 359), Wilkins's most recent account (2018, pp.500-502) attempts to add thereto more precision, specifying that strategic partnerships are 'security alignments'. By this, he draws on the broad understanding of security as developed by the 'Copenhagen school' (Buzan et al., 1998) of critical security studies.

\subsubsection{Towards the Fourth Wave? Theorizing Strategic Partnerships in International Relations}

The research programme on strategic partnerships has evolved mainly through three waves of scholarly debate, as discussed above: the first wave resembled sporadic searches for the meaning of the emerging international-political phenomenon and its conceptualization, which has proven to be contested and incoherent and which has prevented the elaboration of a consensual definition in the first place. As well as the emergence of a disciplinary outlined sub-field of strategic partnerships, the second wave prompted the critical assessment of the studied phenomenon, first and foremost in terms of its relevance, effectiveness and functions in individual actors' foreign policies. The ongoing third wave is characterized by the proliferation and spillover of theoretical 'embedding' of the notion in distinct analytical approaches - from organizational studies to realist, liberal-institutionalist, or constructivist and other strands of theorizing.

In view of the persistence and promise of strategic partnerships in international relations, it appears more than timely and necessary to now focus on developing holistic theoretical accounts of this political phenomenon within and across mainstream and critical theories of international relations and foreign policy. This book's main aim is to provide such an empirically informed holistic theoretical account of strategic partnerships in contemporary international relations, thus aiming to open the next fourth - wave of scholarly debate in the field.

It should be mentioned that until now, only a handful of authors ambitiously attempted and, to a lesser extent, succeeded in theorizing strategic partnerships. In all such cases, the level of conceptual advancement and theoretical embedding has clearly stood out, while falling short of advancing a holistic theoretical argument and framework. It is worth mentioning in this context Wilkins's (2008) pioneering strategic partnership model, including further specifications of his alignment argument (Wilkins, 2015, 2018), Holslag's (2011) twofold approach to strategic partnerships on paper 
and in practice, Czechowska's (2013) ideal model of inter-state strategic partnerships, as well as, more recently, Blanco's $(2015,2016)$ two-level approach (a pluralist theoretical framework combining linguistic and interactionist analysis) and Michalski and Pan's (2017b) three-level analytical framework of strategic partnerships.

Significantly, Michalski and Pan's (2017b) account stands closest to what the SPaSIO project (2013-18) has aimed to pursue: first, both accounts originally focus on strategic partnerships between states and international organizations - unlike the vast majority of other writings in the field that exclusively deal with inter-state partnerships; second, both projects aim at developing holistic theoretical perspectives, thus accounting for: (a) a concept-level analysis in the context of contemporary international relations, (b) inter-relational and intra-relational aspects of strategic partnership, seeking to reveal the rationale for embracing it as a foreign policy tool and the ways it functions within the bilateral framework, and, finally, (c) a systemic level of inquiry, by more broadly establishing what are the role and functions of strategic partnerships as an element of the evolving international system.

Besides that, both projects differ in their actual approaches, design and scope of research programmes, not least in terms of the SPaSIO's promise in developing a holistic, rather than case-specific, theoretical account, which draws on small- $N$ comparative empirical studies, elaborated ontological assumptions as well as solid methodological underpinnings thus combining qualitative and quantitative methods within an integrated methodological framework.

The abductive research strategy, which includes steps of comparison of research findings from 14 individual case studies as well as their validation against the backdrop of original assumptions and existing theoretical claims (SPSS-based statistical hypothesis testing, with subsequent revision of the model in light of the findings), has been devised within the current project to ensure the validity and extrapolability of theoretical propositions - a pioneering effort in the field.

\section{REFERENCES}

Adelle, C. and Kotsopoulos, J. (2017). The EU-South Africa strategic partnership and global environmental governance: towards effective multilateralism after Copenhagen? South African Journal of International Affairs 24(2), 229-48.

Adler, E. and Pouliot, V. (2011). International practices. International Theory 3(1), $1-36$.

ASEAN (2018). ASEAN-External Relations. ASEAN Official Webpage. Retrieved 16 July 2018 from http://asean.org/asean/external-relations 
Bache, I. (2010). Partnership as an EU policy instrument: a political history. West European Politics 33(1), 58-74.

Bang, J. (2017). Why so many layers? China's 'state-speak' and its classification of partnerships. Foreign Policy Analysis 13(2), 380-97.

Blanco, L. F. (2015). On the uses and functions of 'strategic partnership' in international politics: Implications for agency, policy and theory ( $\mathrm{PhD}$ thesis). Bielefeld: Bielefeld University.

Blanco, L. F. (2016). The functions of 'strategic partnership' in European Union foreign policy discourse. Cambridge Review of International Affairs 29(1), 36-54.

Brzezinski, Z. (1997). The Grand Chessboard: American Primacy and Its Geostrategic Imperatives. New York: Basic Books.

Burns, W. J. (2009). The practice of partnership: the 2009 Cyril Foster Lecture. Lecture delivered at the University of Oxford, 26 November. Retrieved 17 May 2010 from http://www.state.gov/p/us/rm/2009a/133268.htm

Buzan, B., Wæver, O. and Wilde, J. D. (1998). Security: A New Framework for Analysis. Boulder, CO: Lynne Rienner.

Czechowska, L. (2013). Wewnatrzunijni partnerzy strategiczni Rzeczypospolitej Polskiej [Poland's Intra-EU Strategic Partners]. Toruń: MADO.

Delors, J. (1985). A speech by Jacques Delors at the First Intergovernmental Conference, Luxembourg, 9 September. Bulletin of the European Communities 9. Luxembourg: Office for Official Publications of the European Communities. Retrieved 3 July 2018 from https://www.cvce.eu/content/publication/ 2001/10 /19/423d6913-b4e2-4395-9157-fe70b3ca8521/publishable_en.pdf

Elrod, R. and Mielish, J. (2018). Strategic partnerships: thinking outside the administrative box. Community College Journal of Research and Practice 42(9), 617-22.

Emerson, M. (ed.), with Arbatova, N., Bordachev, T., Makarychev, A. S., Tassinari, F., Vahl. M. and European Round Table of Industrialists (2001). The Elephant and the Bear: the European Union, Russia and their Near Abroads. Brussels: Centre for European Policy Studies.

Envall, H. D. P. and Hall, I. (2016). Asian strategic partnerships: new practices and regional security governance. Asian Politics \& Policy 8(1), 87-105.

Eurasian Economic Commission (2017). Achieving the Sustainable Development Goals in the Region of the Eurasian Economic Union. Report of the Eurasian Economic Commission. Retrieved 15 July 2018 from http://www.eurasiancom mission.org/ru/act/integr_i_makroec/dep_razv_integr/Documents/Издания/OO N_Eng.pdf

European Council (2003). A Secure Europe in a Better World: European Security Strategy. Brussels, 12 December. Retrieved 11 July 2018 from https://europa.eu/ globalstrategy/en/european-security-strategy-secure-europe-better-world

European Council (2010). Press release of the President of the European Council, 14 September. Retrieved 11 July 2018 from http://www.consilium.europa.eu/ue docs/cms_Data/docs/pressdata/en/ec/116494.pdf

Farias, R. de S. (2013). Parcerias estratégicas: marco conceitual. In A. C. Lessa and H. A. de Oliveira (Org.), Parcerias estratégicas do Brasil: os significados e as experiências tradicionais, vol. 1. Belo Horizonte: Fino Traço, pp. 15-35.

Ferreira-Pereira, L. C. (2016). The European Union's partnership policy towards Brazil: more than meets the eye. Cambridge Review of International Affairs 29(1), 55-77. 
Ferreira-Pereira, L. C. and Vieira, A. V. G. (2016). Introduction: The European Union's strategic partnerships: conceptual approaches, debates and experiences. Cambridge Review of International Affairs 29(1), 3-17.

FMPRC (2015). Foreign Minister Wang Yi meets the press after the Third Session of the Twelfth National People's Congress, 8 March. Retrieved 22 July 2018 from http://www.fmprc.gov.cn/mfa_eng/wjb_663304/wjbz_663308/2461_663310/t124 3662.shtml

Geldenhuys, D. (2015). The comprehensive strategic partnership between South Africa and Russia. Strategic Review for Southern Africa 37(2), 118-45.

Gilson, J. (2016). The Strategic Partnership Agreement between the EU and Japan: the pitfalls of path dependency? Journal of European Integration 38(7), 791-806.

Gratius, S. (2012). Brazil and the European Union: between balancing and bandwagoning. ESPO Working Paper 2 (July).

Grevi, G. (2010). Making EU strategic partnerships effective. FRIDE Working Paper 105 (December).

Grevi, G. (2012). Why EU strategic partnerships matter. ESPO Working Paper 1 (June).

Grevi, G. (2013). The EU Strategic Partnerships: process and purposes. In M. Telò and F. Ponjaert (eds.), The EU's Foreign Policy: What Kind of Power and Diplomatic Action. Farnham: Ashgate, pp. 159-73.

Grevi, G. and Renard, T. (2012). Hot issues, cold shoulders, lukewarm partners: EU strategic partnerships and climate change. ESPO Report 2 (November).

Hamilton, D. S. (2014). The American way of partnership. ESPO Working Paper 6 (July).

Holslag, J. (2011). The elusive axis: assessing the EU-China strategic partnership. Journal of Common Market Studies 49(2), 293-313.

Hosoya, Y. (2012). The evolution of the EU-Japan relationship: towards a 'normative partnership'? Japan Forum 24(3), 317-37.

Iankova, E. A. (2009). Business, Government, and EU Accession: Strategic Partnership and Conflict. Lanham, MD: Lexington Books.

Kay, S. (2000). What is a strategic partnership? Problems of Post-Communism 47(3), $15-24$.

Kliman, D. M., Walker, J. W. and Inboden, W. (2014). Promising partnerships: emerging and established powers in the 21st century. GMF Emerging Powers Policy Forum (March).

Laipson, E. (2015). For 21st-century problems, states seek partnerships, not alliances. World Politics Review, 15 July. Retrieved 22 July 2018 from https://www.worldpoli ticsreview.com/trend-lines/16238/for-21st-century-problems-states-seek-partner ships-not-alliances

Lessa, A. C. (1998). A diplomacia universalista do Brasil: A construção do sistema contemporâneo de relações bilaterais. Revista brasileira de política internacional 41 (special issue), 29-41.

Lessa, A. C. (2010). Brazil's strategic partnerships: an assessment of the Lula era (2003-2010). Revista Brasileira de Política Internacional 53 (special issue), $115-31$.

Lo, B. (2008). Axis of Convenience: Moscow, Beijing, and the New Geopolitics. London and Washington, DC: Chatham House and Brookings Institution Press.

Maher, R. (2016). The elusive EU-China strategic partnership. International Affairs 92(4), 959-76.

Menon, R. (2007). The End of Alliances. Oxford: Oxford University Press. 
Michalski, A. and Pan, Z. (2017a). Role dynamics in a structured relationship: the EU-China strategic partnership. JCMS: Journal of Common Market Studies 55(3), 611-27.

Michalski, A. and Pan, Z. (2017b). Unlikely Partners? China, the European Union and the Forging of a Strategic Partnership. Singapore: Palgrave Macmillan.

Milner, H. (1992). International theories of cooperation among nations: strengths and weaknesses. World Politics 44(3), 466-96.

Moscow Declaration by US President Clinton and Russian President Yeltsin (1994). Moscow, Russia, 14 January. Retrieved 23 July 2018 from http://fas.org/ nuke/control/detarget/docs/940114-321186.htm

Murray, P. (2016). EU-Australia relations: a strategic partnership in all but name? Cambridge Review of International Affairs 29(1), 171-91.

Nadkarni, V. (2010). Strategic Partnerships in Asia: Balancing without Alliances. London and New York: Routledge.

Nath, S. (2014). Strategic partnership for economic development: India's new 'inclusive trade diplomacy'. Procedia: Social and Behavioral Sciences 157, $236-43$.

NYT Chronicle (2015). 'Strategic partnership' in the NYT news coverage. Retrieved 21 July 2018 from http://chronicle.nytlabs.com

Oviedo, E. D. (2006). China: visión y práctica de sus llamadas 'relaciones estratégicas'. Estudios de Asia y África 41(3), 385-404.

Paul, T. V. (2018). When balance of power meets globalization: China, India and the small states of South Asia. Politics (OnlineFirst edition), 6 June. Retrieved 19 July 2018 from doi: 0263395718779930

Powell, R. (1999). In the Shadow of Power: States and Strategies in International Politics. Princeton, NJ: Princeton University Press.

Renard, T. (2011a). EU foreign ministers should look to 'grand strategy'. EU Observer, 30 August. Retrieved from https://euobserver.com/opinion/113442

Renar, T. [Reynard, T.] (2011b). Vneshniaya polityka ES: ot dialoha o stratehicheskom partnerstve $\mathrm{k}$ real'nomu stratehicheskomu partnerstvu. Vestnyk mеzhdunarodnikh orhanyzatsiy [Вестник международных организачий] 4(35), 92-117.

Renard, T. (2012). The EU strategic partnerships review: ten guiding principles. ESPO Policy Brief 2 (April).

Renard, T. (2013). The EU and its strategic partners: a critical assessment of the EU's strategic partnerships. In S. Biscop and R. G. Whitman (eds.), The Routledge Handbook of European Security. London and New York: Routledge, pp. 302-14.

Renard, T. (2014). The rise of cyber-diplomacy: the EU, its strategic partners and cyber-security. ESPO Working Paper 7 (June).

Renard, T. (2016a). Partnering for global security: the EU, its strategic partners and transnational security challenges. European Foreign Affairs Review 21(1), 9-33.

Renard, T. (2016b). Partnerships for effective multilateralism? Assessing the compatibility between EU bilateralism, (inter-)regionalism and multilateralism. Cambridge Review of International Affairs 29(1), 18-35.

Renard, T. (2018). EU cyber partnerships: assessing the EU strategic partnerships with third countries in the cyber domain. European Politics and Society 19(3), 321-37.

Sachdeva, G. (2015). Evaluation of the EU-India strategic partnership and the potential for its revitalization. EP AFET Study, EP/EXPO/B/AFET/FWC/201308/Lot5/05. Brussels: European Parliament (June). 
Saprykin, V. (2001). Zasady stratehichnoho partnerstva. Stenohrama kruhloho stolu UCEPD (3 January). Retrieved 6 May 2015 from http://www.razumkov. org.ua/ukr/article.php?news_id=113

Sautenet, A. (2007). The current status and prospects of the 'strategic partnership' between the EU and China: towards the conclusion of a partnership and cooperation agreement. European Law Journal 13(6), 699-731.

SGCAN (2017). Secretaría General de la CAN y Comisión Económica Euroasiática (CCE) firman Memorándum de Entendimiento. Lima (24 March). Retrieved 20 July 2018 from http://www.comunidadandina.org/Prensa.aspx?id=3825\&accion $=$ detalle $\&$ cat $=$ NP\&title $=$ secretaria-general-de-la-can-y-comision-economica-eu roasiatica-cce-firman-memorandum-de-entendimiento

Slobodchikoff, M. O. and Tandon, A. (2017). Shifting alliances and balance of power in Asia: transitions in the Indo-Russian security ties. Asian Journal of Political Science 25(2), 159-75.

Taneja, P. (2010). China-Europe relations: the limits of strategic partnership. International Politics 47(3-4), 371-87.

Trinidad, D. D. (2017). Domestic factors and strategic partnership: redefining Philippines-Japan relations in the 21st century. Asian Politics \& Policy 9(4), 613-35.

Tyushka, A. (2010). Instrumentalizatsiia analitychnykh katehoriy u doslidzhenni nimets'ko-frantsuz'kykh bezpekovo-oboronnykh vidnosyn: «osoblyvi vidnosyny», «stratehichne partnerstvo» chy «mizhnarodnyy rezhym»? Robochyy dokument, 24 February. Lviv: LNU im. Ivana Franka, Fakultet mizhnarodnykh vidnosyn.

Vieira, A. (2016). Ukraine, Russia and the strategic partnership dynamics in the EU's eastern neighbourhood: recalibrating the EU's 'self', 'we' and 'other'. Cambridge Review of International Affairs 29(1), 128-50.

Wang, S. (2017). Sino-Swiss strategic partnership: a model for China-Europe relations. China Quarterly of International Strategic Studies 3(2), 267-82.

Watson, A. M. S. (2001). Strategic partnership. In R. J. Barry Jones (ed.), Routledge Encyclopedia of International Political Economy. London and New York: Routledge, pp. 1488-90.

Wilkins, T. S. (2008). Russo-Chinese strategic partnership: a new form of security cooperation? Contemporary Security Policy 29(2), 358-83.

Wilkins, T. S. (2012). 'Alignment', not 'alliance': the shifting paradigm of international security cooperation - toward a conceptual taxonomy of alignment. Review of International Studies 38(1), 53-76.

Wilkins, T. S. (2015). From strategic partnership to strategic alliance? AustraliaJapan security ties and the Asia-Pacific. Asia Policy 20, 81-112.

Wilkins, T. S. (2018). After a decade of strategic partnership: Japan and Australia 'decentering' from the US alliance? The Pacific Review 31(4), 498-514.

WPR (2018). In deepening ties with ASEAN, Australia gains a 'strategic hedge' [Editorial]. World Politics Review, 28 March. Retrieved 26 July 2018 from https://www.worldpoliticsreview.com/trend-lines/24455/in-deepening-ties-withasean-australia-gains-a-strategic-hedge

Yang, J. (2007). Work together to build a common future. Speech by foreign minister Yang Jiechi at the Royal Institute of International Affairs, London, 5 December. Retrieved 23 July 2018 from http://www.fmprc.gov.cn/mfa_eng/wjdt_665385/ zyjh_665391/t387186.shtml

Zhovkva, I. I. (2005). Stratehichne partnerstvo u zovnishniy̆ politytsi Ukraiiny (Dysertatsia na zdobutia nauk. stupenia kand. polit. nauk: spetsial'nist' 23.00.04. 
«Politychni problemy mizhnarodnykh system ta hlobalnoho rozvytku»). Kyiv: KNU im. T. Shevchenka. Retrieved 28 June 2018 from http://nbuv.gov.ua/ node $/ 2116$

Zhovkva, I. I. (2006). Stratehichne partnerstvo Ukraiiny. Teoriia i praktyka (Za zah. red. akademika NAN Ukrayiny, d.t.n. V.P. Horbulina). Kyiv: DP NVTS 'Yevroatlantykinform'. 